\title{
TRAVEL TIME TOMOGRAPHY MENGGUNAKAN DATA SEISMIK INTERFEROMETRI UNTUK MENGGAMBARKAN MODEL KECEPATAN GELOMBANG PADA LAPANGAN " $X$ ”
}

\author{
Radifan Taufik, Firman Syaifuddin, Mariyanto \\ Departemen Teknik Geofisika, Fakultas Teknik Sipil Lingkungan dan Kebumian, Institut Teknologi Sepuluh Nopember, \\ Surabaya \\ e-mail : radifantaufik09@gmail.com
}

\begin{abstract}
Abstrak. Pengolahan data seismik interferometri mulai dikembangkan untuk menggambarkan kondisi bawah permukaan bumi. Metode ini dapat mengekstrak informasi kecepatan gelombang dari suatu noise sehingga menyajikan informasi-informasi kecepatan gelombang yang tidak bisa didapatkan menggunakan metode seismik konvensional. Selain itu metode ini merupakan metode yang ramah lingkungan serta biaya yang dikeluarkan tidak banyak. Terdapat beberapa metode untuk menggambarkan hasil perhitungan seisimik interferometri, salah satunya ialah traveltime tomography. Oleh karena itu dilakukan penelitian ini untuk menggambarkan kecepatan gelombang pada lapangan ' $X$ ' untuk menyajikan data kecepatan gelombang menggunakan metode traveltime tomografi. Stasiun yang digunakan berjumlah 68 dan tersebar secara merata. Data raw yang digunakan berupa data travel time dan lokasi pada setiap virtual source ke setiap stasiun. Tahapan pengolahan diawali dengan pembuatan model sintetik sebagai media pengujian resolusi berupa checkerboard model. Model tersebut sangat baik dalam menentukan inversi tomografi yang optimal. Setelah itu dilakukan inversi tomografi menggunakan metode pseudo inverse. Hasil inversi tomografi memperlihatkan adanya perubahan kecepatan mulai dari model homogen pada iterasi ke 1 hingga terdapat kontras kecepatan gelombang berkisar $40-200 \mathrm{~m} / \mathrm{s}$ pada iterasi 12. .
\end{abstract}

Kata Kunci: travel time tomography; interferometri; model kecepatan gelombang

\begin{abstract}
Seismic interferometry processing has been developed for imaging subsurface. This method alow us to extract some information of wave velocity that seismic conventional method can't get. Moreover, this method is eco-friendly and also does not cost a lot, because of the pasif source. There are some methods to do an imaging velocity model of seismic interferometry data, one of those method is travel time tomography. Hence, the writer do a research of traveltime tomography to provide velocity model using seismic interferometry data. The number of used stations are 68 that spread evenly in " $X$ " field. Travel time and the location of all stations is used as raw data. This processing is start with inversion tomography of synthetic checkerboard model as a resolution test. Checkerboard model is suitable for a resolve optimal inversion tomography. Afterward, pseudo inverse is used to complete the inversion tomography. The result of inversion tomogaphy showed that there is a change in velocity model, from relatively homogenous model at first iteration until showing a contrast velocity model at the last iteration with values ranging from $40 \mathrm{~m} / \mathrm{s}-200 \mathrm{~m} / \mathrm{s}$.
\end{abstract}

Keywords: travel time tomography; interferometry; velocity model

\section{PENDAHULUAN}

Akuisisi metode seismik pasif mulai dikembangkan oleh T. Schuster (2001) dengan menyajikan perhitungan matematis yang dapat mengubah respon dari virtual source menjadi respon seismik konvensional menggunakan teknik interferometri yang memanfaatkan ambient noise sebagai sumber yang kemudian direkam untuk mengkarakteristik batuan dibawah permukaan tanah. Seismik interferometri merupakan metode seismik pasif yang menggunakan korelasi antara trace data seismik, korelasi ini mengacu pada interferensi antara pasangan sinyal untuk mendapatkan informasi dari keduanya (Wapenaar, dkk. 2010). Setelah mengaplikasikan teknik interferometri kemudian perlu teknik tomografi untuk menggambarkan peta model kecepatan.

Tomografi seismik adalah sebuah metode untuk menggambarkan kondisi bawah permukaan bumi menggunakan data seismik yang terekam di permukaan bumi. Gelombang seismik yang digunakan biasanya bersumber dari adanya gempa bumi besar maupun kecil. Wilayah yang memiliki aktivitas seismik yang cukup tinggi akan sangat 
bagus menerapkan metode ini dikarenakan banyaknya raypath yang dapat dimanfaatkan untuk mengoptimalkan hasil pencitraan tomografi. (Anshori dkk., 2014).

Terdapat beberapa macam metode geofisika yang dapat digunakan untuk mencitrakan struktur bawah permukaan bumi seperti metode seismik
Data yang digunakan merupakan data sekunder dari pihak ketiga. Rekaman data diakuisisi di lapangan ' $X$ ', kabupaten Asmat, berupa rekaman micro earthquake (MEQ) yang telah diolah menggunakan seismik inteferometri hingga mendapat travel time dari virtual source ke setiap stasiun. Gambar 1 merupakan persebaran stasiun-

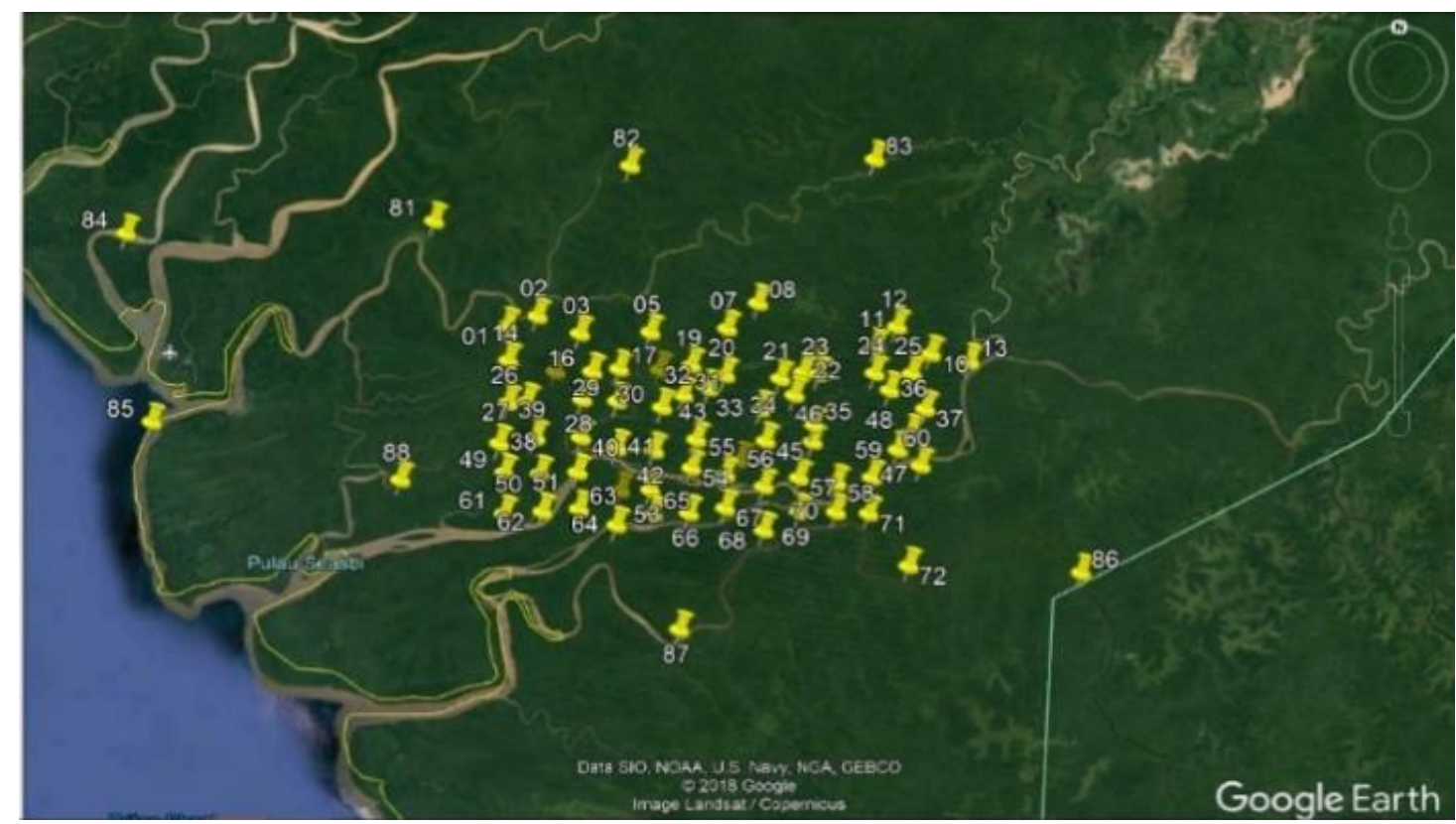

Gambar 1. Persebaran stasiun yang digunakan pada lapangan ' $X$ ' dengan jumlah 66 stasiun.

tomografi, surface wave group velocity, array seismology, dan receiver function. Diantara sekian metode, salah satu metode seismik yang paling sering dan paling baik digunakan ialah travel time tomography. Travel time tomography merupakan salah satu metode untuk merekonstruksi struktur bawah permukaan bumi dengan data-data seismik yang terekam pada receiver yang memanfaatkan data waktu tempuh gelombang. Konsep dasar metode tomografi travel time adalah menggambarkan kondisi struktur bawah permukaan bumi dengan melakukan pemodelan kedepan dan pemodelan kebelakang yang dilakukan secara berulang hingga diperoleh data travel time hasil perhitungan berdasarkan model terbaru yang paling sesuai dengan data travel time observasi (Hidayatunnisak, dkk., 2015).

Pada penelitian kali ini akan dilakukan traveltime tomography menggunakan data seismik interferometry untuk menggambarkan model kecepatan pada lapangan " $X$ ". stasiun. Jumlah stasiun yang digunakan sebanyak 68 stasiun dengan waktu perekaman selama 5 bulan, namun proses stacking trace yang digunakan untuk picking traveltime hanya 1 jam perekaman data. Seluruh proses pengolahan data menggunakan MATLAB. Berikut ditampilkan diagaram alir penelitian pada Gambar 2.

\section{METODOLOGI}




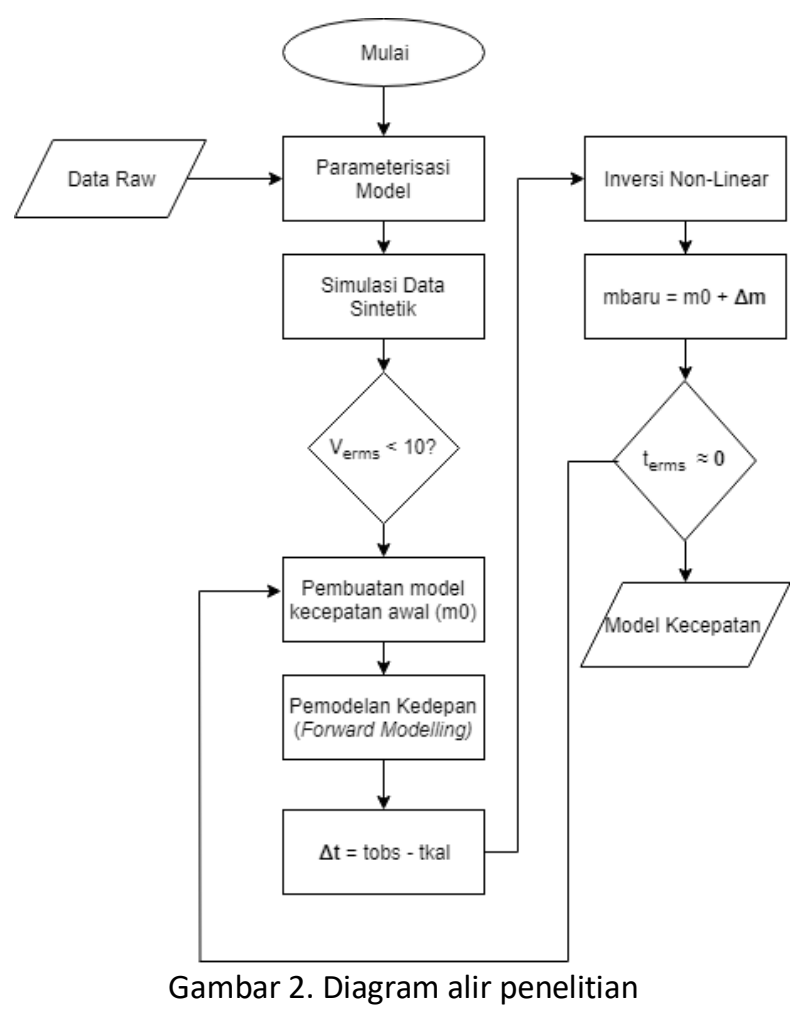

Pada tahap awal penulis menyiapkan data raw berupa lokasi-lokasi stasiun serta travel time dari satu stasiun ke semua stasiun.

Proses tomografi diawali dengan simulasi data sintetik menggunakan model chekcerboard sebagai uji resolusi. Model checkerboard mampu dapat menentukan resolusi yang dihasilkan dengan jumlah stasiun dan jumlah raypath akan menghasilkan inversi yang baik atau kurang baik. Baik atau tidaknya hasil inversi dari checkerboard model ini ditentukan dengan terms antara true model dengan model hasil dari inversi.

Pemodelan kedepan (forward modelling) menggunakan metode Fast Marching Method (FMM) dengan pendekatan finite difference (Vidale, 1988). Dari hal ini penulis mendapatkan nilai selisih antara travel time hasil picking (tobs) dan travel time yang didapat dengan metode FMM (tkal).

Untuk metode raytracing menggunakan metode steepest descent yang telah ditulis oleh ( $F$. Aldridge dan Oldenburg, 1993).

Inversi non-linear yang digunakan pada model checkerboard dan data lapangan ialah metode pseudo inverse. Hasil inversi berupa model slowness yang kemudian dilakukan pembaharuan model. Model baru tersebut akan menjadi model awal ( $\mathrm{m0}$ ) dan model awal tersebut akan di inversi lagi. Proses iterasi inversi akan berlangsung secara terus menerus sampai dengan kondisi yang telah ditentukan. Penulis menetapkan kondisi berdasarkan nilai $t_{\text {erms. }}$.

\section{HASIL DAN PEMBAHASAN}

Proses pengolahan diawali dengan simulasi data sintetik menggunakan model checkerboard dengan variasi kecepatan $500 \mathrm{~m} / \mathrm{s}$ dan $1000 \mathrm{~m} / \mathrm{s}$. Pada sumbu $x$ dimasukkan data lokasi UTM North sedangkan pada sumbu y lokasi UTM East. Rentang sumbu $x$ yang dibuat ialah 200000 sampai 286000 dengan lebar sel 1000 . Pada sumbu y rentang yang dibuat ialah 9361000 sampai 9413000 dengan lebar sel 1000. Dari parameter tersebut menghasilkan ukuran sel sebesar $53 \times 87$.

Gambar 3 menampilkan model checkerboard dengan lokasi semua stasiun. Stasiun-stasiun yang digunakan ditandai dengan segitiga berwarna merah.

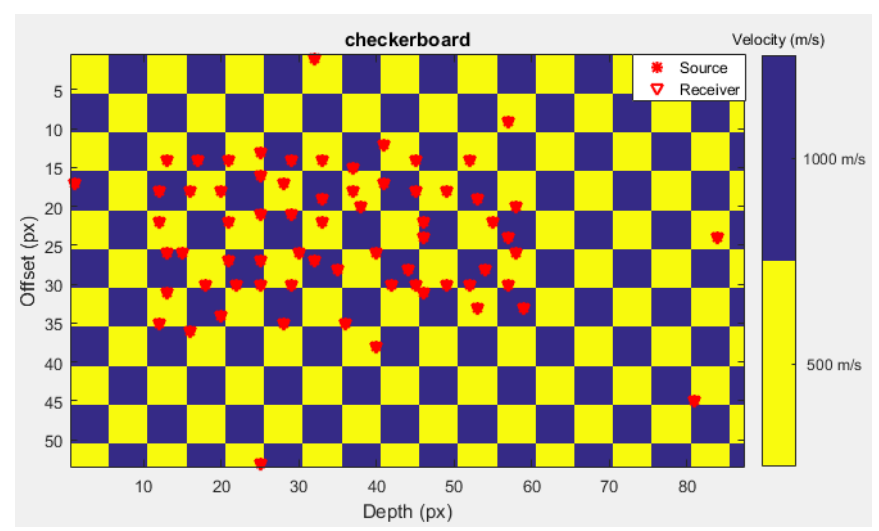

Gambar 3. Lokasi stasiun-stasiun yang digunakan dengan jumlah 68 buah 


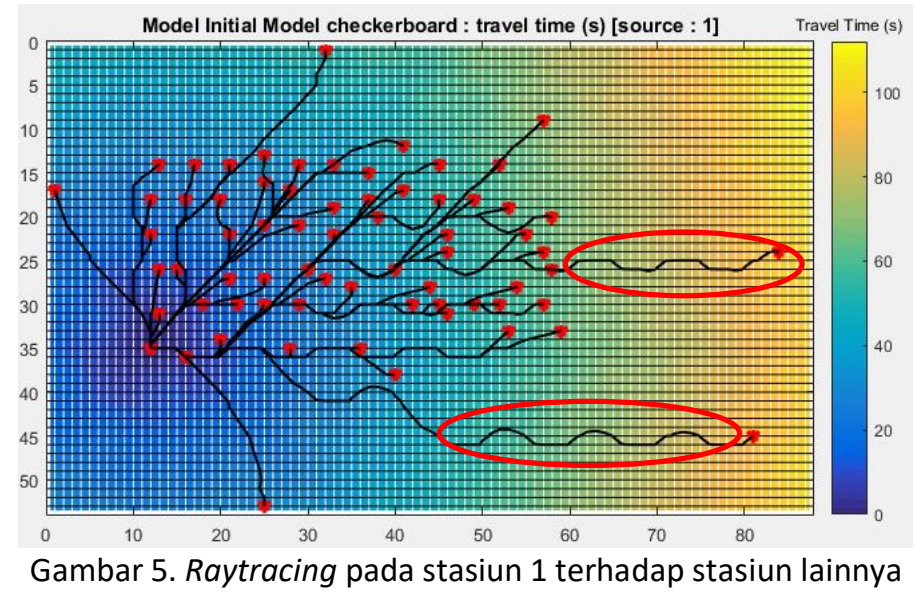

Proses tomografi yang dilakukan pada model checkherboard secara garis besar dapat dibagi menjadi 4 tahap, yaitu:

1. Perhitungan first arrival traveltime dari setiap pasang source dan receiver pada initial model.

2. Penelusuran jejak sinar dari setiap pasang source dan receiver

3. Perhitungan permasalahan inversi non-linier dari perturbasi untuk initial model slowness.

4. Memperbaharui model slowness.

Keempat tahap tersebut dilakukan berulang kali sampai dengan iterasi 10 . Keempat proses ini di inisiasi menggunakan model checkerboard juga, namun dengan kecepatan yang berbeda dimana kecepatan initial model yang digunakan adalah $1000 \mathrm{~m} / \mathrm{s}$ dan $1500 \mathrm{~m} / \mathrm{s}$. Pada Gambar 4, menunjukkan model checkerboard sebagai initial model untuk melakukan tomografi inversi pada model checkerboard.

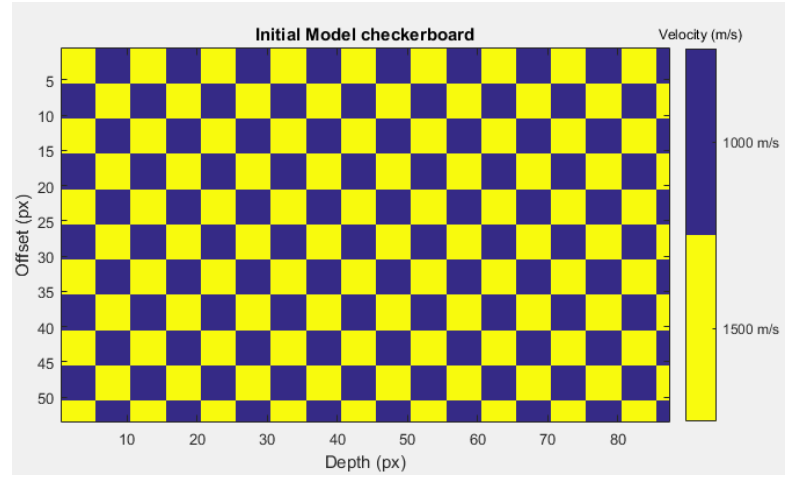

Gambar 4. Initial model checkerboard dengan kecepatan $1000 \mathrm{~m} / \mathrm{s}$ dan $1500 \mathrm{~m} / \mathrm{s}$

Perhitungan first arrival time dilakukan menggunakan persamaan eikonal dengan finite difference. Perhitungan ini dilakukan pada setiap source ke semua receiver. Perhitungan travel time dilakukan pada true model untuk mendapatkan time observasi dan pada initial model checkerboard yang akan didefinisikan sebagai time kalkulasi. Kemudian didapatkan selisih waktu tempuh nilai antara true model dengan initial model $(\Delta \mathrm{t})$. Nilai selisih inilah yang akan digunakan pada tahap inversi.

Gambar 5 merupakan contoh raytracing pada source 1 terhadap semua receiver. Pada lingkaran merah menunjukkan bahwa raypath akan menelusuri kecepatan yang lebih tinggi $(1500 \mathrm{~m} / \mathrm{s})$.

Pola lekukan yang terbentuk pada lingkaran warna merah terjadi karena medium kecepatan tinggi membentuk kotak (model checkerboard). Pola lekukan tersebut banyak dijumpai pada source yang lain, terutama saat posisi source dan receiver sejajar pada sumbu $x$ maupun sumbu $y$.

Kemudian proses dilanjutkan inversi menggunakan pseudo inverse dimana matriks yang dihasilkan dari pseudo inverse tersebut kemudian dikalikan dengan travel time $(\Delta \mathrm{t})$. Perkalian tersebut menghasilkan model slowness hasil inversi. Kemudian model slowness hasil inversi tersebut ditambah dengan initial model slowness sehingga didapatkan model slowness baru. Model slowness baru ini kemudian didefinisikan sebagai intial model baru yang akan dilakukan tahap forward modelling pada iterasi berikutnya. Iterasi dilakukan sebanyak 10 kali.

Setelah hasil inversi didapatkan kemudian dihitung nilai errornya, dimana nilai error yang dihitung ialah selisih antara tobs dengan tkal ( $\left.t_{\text {erms }}\right)$. 


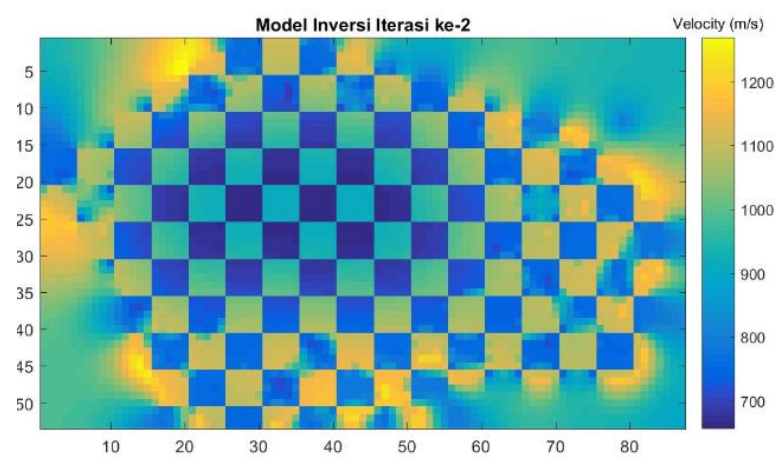

Gambar 6. Inversi model checkerboard pada iterasi ke-2

Pada Gambar 6 merupakan hasil inversi pada iterasi kedua. Model kecepatan yang dihasilkan pada iterasi kedua belum menghasilkan inversi yang cukup baik dimana nilai $t_{\text {erms }}$ nya masih $0.42055 \%$. Pada setiap iterasi, hasil model slowness diterapkan smoothing velocity untuk menghasilkan model kecepatan yang cukup baik dimana smoothing velocity ini akan mengurangi nilai kontras kecepatan yang tinggi. Kemudian solusi untuk sel-sel yang tidak dilewati raypath ialah dengan memanfaatkan function inpaint pada MATLAB dimana function ini akan melakukan ekstrapolasi pada sel-sel yang tidak dilalui raypath tersebut.

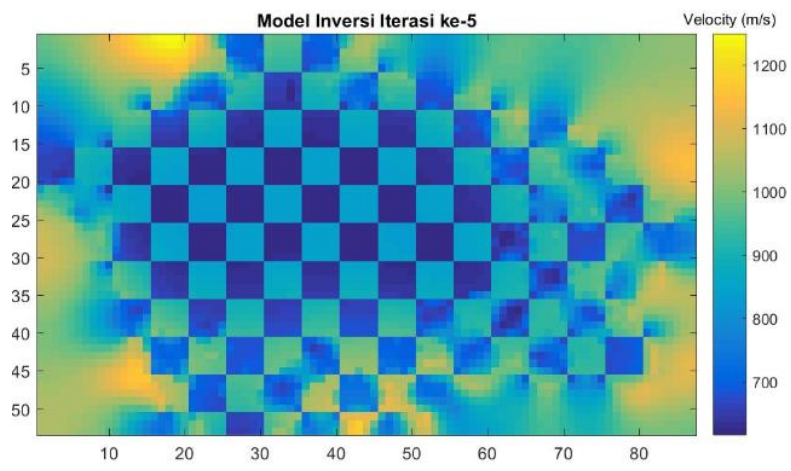

Gambar 7. Inversi model checkerboard pada iterasi ke-5

Gambar 7 merupakan hasil inversi pada iterasi ke-5. Dapat terlihat bahwa model kecepatan yang dihasilkan semakin membaik, sesuai dengan penelitian F. Aldridge dan Oldenburg (1993) dimana setiap iterasinya hasilnya akan semakin baik. Iterasi dilakukan sebanyak 10 kali, pada setiap iterasi terjadi penurunan $t_{\text {erms. }}$.

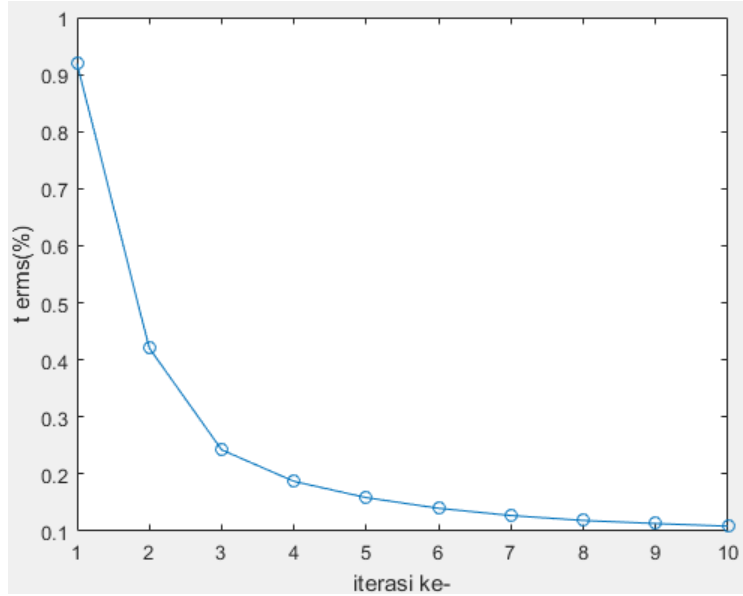

Gambar 8. Nilai terms pada setiap pembaharuan model (iterasi)

Pada Gambar 8. menunjukkan nilai terms pada setiap iterasi, dimana dapat terlihat bahwa nilai $t_{\text {erms }}$ pada setiap iterasi nya mengalami penurunan yang cukup signifikan. Hal ini menunjukkan selisih antara time kalkulasi dengan time observasi semakin kecil, sehingga model slowness hasil tomography mendekati nilai true model slowness

Melihat dari hasil tomography pada model checkerboard tersebut dapat dinyatakan bahwa geometri persebaran stasiun, jumlah stasiun serta jumlah raypath yang digunakan akan menghasilkan inversi yang baik menggunakan data travel time pada lapangan, sesuai yang dilakukan oleh Nicolson dkk. (2012).

Setelah teknik tomography berhasil dilakukan pada model checkerboard, kemudian dilakukan travel time tomography menggunakan data tobs pada lapangan. Initial model diawali menggunakan model homogen dengan kecepatan $1000 \mathrm{~m} / \mathrm{s}$. Penentuan model kecepatan homogen merupakan trial\&error dimana pada model kecepatan ini lah yang paling baik.

Langkah - langkah yang dilakukan sama seperti yang dilakukan pada simulasi model sintetik, namun untuk iterasi pertama tidak menggunakan bending ray namun menggunakan straight ray dikarenakan hasil inversi pada iterasi pertama sangat penting, ketika hasil inversi pada iterasi pertama tidak baik, maka pada iterasi selanjutnya tidak akan merepresentasikan model yang kecepatan baik. Dengan menggunakan straight ray maka perhitungan traveltime lebih akurat dibandingkan dengan bending ray. 


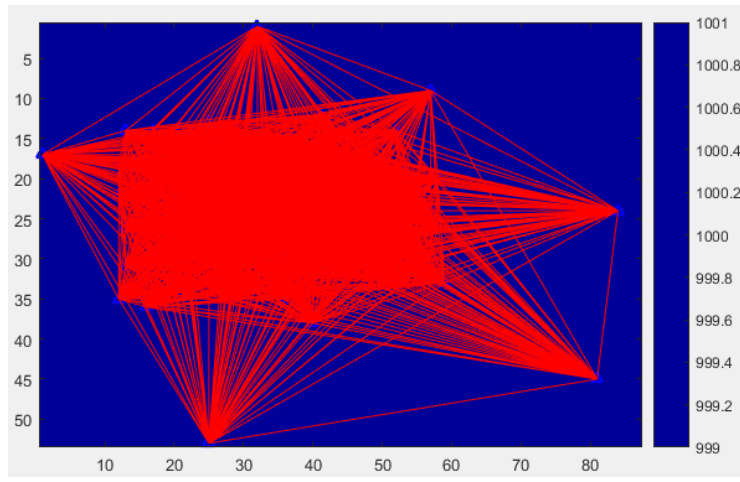

Gambar 9. Model kecepatan homogen dengan

kecepatan $1000 \mathrm{~m} / \mathrm{s}$ serta raypath dari setiap pasang source dan receiver pada model homogen yang ditandai dengan garis berwarna merah

Pada Gambar 9 menunjukkan raypath dari setiap pasang source dan receiver dengan raypath di tandai dengan garis berwarna merah.

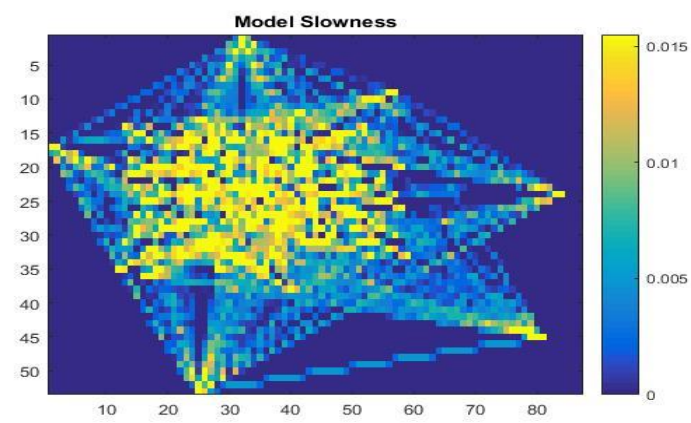

Gambar 10. Model slowness hasil inversi pada model homogen dengan indeks warna menunjukkan nilai slowness

Model slowness hasil inversi ditunjukkan pada Gambar 10. Pada gambar tersebut terlihat bahwa pada hasil persoalan inversi tidak terlihat baik dikarenakan setiap raypath coverage pada setiap sel berbeda-beda, sehingga tidak menujukkan keseragaman nilai slowness, terutama pada daerah sel yang tidak dilewati raypath terlihat jelas dimana nilai slownessnya adalah 0 . Namun pada daerah dengan raypath coverage tinggi terlihat bahwa terdapat keseragaman nilai slowness yang ditandai dengan lingkaran berwarna merah. Untuk mendapatkan nilai slowness yang lebih baik maka dilakukan smoothing pada model slowness tersebut.

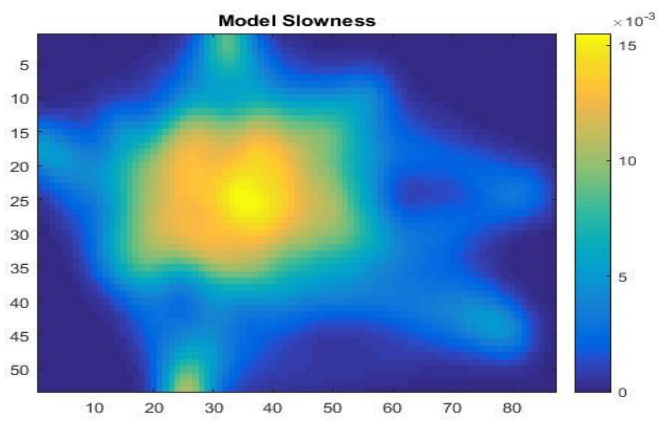

Gambar 11. Model slowness setelah dilakukan proses smoothing

Proses smoothing menggunakan toolbox Crewes MATLAB dengan parameter smoothing 4 pada skala toolbox tersebut. Penulis melakukan uji coba parameter smoothing untuk menentukan parameternya, sehingga didapat, menurut penulis, parameter smoothing pada toolbox Crewes ialah 4. Gradasi warna dari hasil smoothing jauh lebih baik dibandingkan dengan sebelum dilakukan smoothing. Model slowness setelah dilakukan smoothing ditunjukkan pada Gambar 11.

Kemudian dilakukan ekstrapolasi pada sel-sel yang tidak dilewati raypath sehingga nilai pada selsel tersebut mendekati dengan nilai sel yang terdekat. Hasil dari ekstrapolasi ditunjukkan pada Gambar 12 dimana hasil akhirnya jauh lebih baik dibandingkan dengan model slowness tanpa smoothing maupun ekstrapolasi.

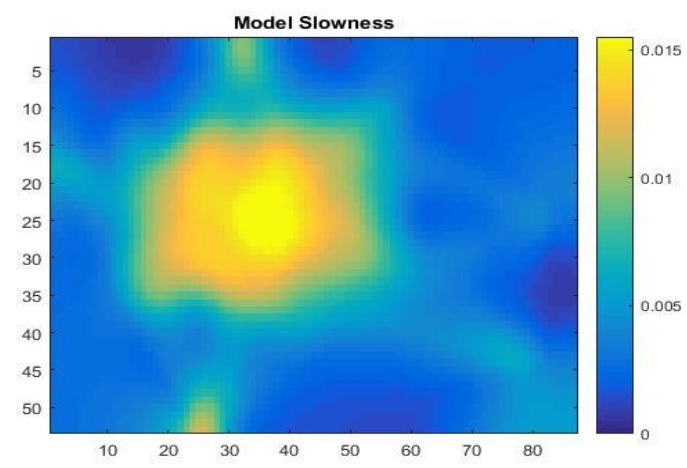

Gambar 12. Model slowness setelah dilakukan proses smoothing dan ekstrapolasi

Setelah mendapatkan nilai model slowness yang cukup baik, barulah dapat mengubah menjadi model kecepatan. Berikut ditampilkan model kecepatan yang dihasilkan pada Gambar 13. 


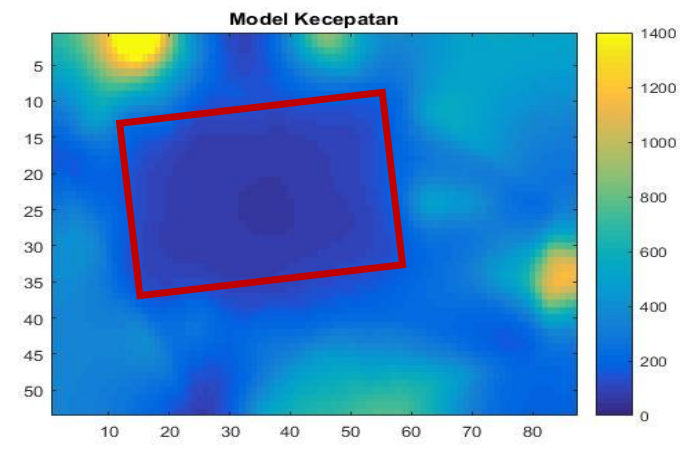

Gambar 13. Model kecepatan yang didapatkan dari hasil tomografi pada model homogen

Pembaharuan model sangat diperlukan agar model hasil tomografi mendekati dengan true model. Selain itu pembaharuan model akan selalu mengurangi nilai selisih antara $t_{\text {obs }}$ dan $t_{\text {kal }}$ sehingga menghasilkan nilai $t_{\text {erms }}$ yang semakin kecil pada setiap iterasinya. Iterasi akan terus berlangsung sampai ditentukan dimana perubahan nilai $t_{\text {erms }}$ relatif konstan tiap iterasinya. Langkah-langkah yang digunakan sama seperti yang dilakukan pada simulasi model sintetik checkerboard.

Iterasinya dilakukan sebanyak 12 kali dikarenakan perubahan $t_{\text {erms }}$ relatif konstan mulai dari iterasi 7. Mulai dari iterasi 1 sampai iterasi ke 7 , penurunan nilai terms cukup signifikan.

Kemudian nilai $t_{\text {erms }}$ di plot menjadi grafik sehingga dapat terlihat trend yang terbentuk. Pada Gambar 14 dapat terlihat bahwa trend $t_{\text {erms }}$ mengalami penurunan yang signifikan hingga pada iterasi ke-7. Pada iterasi ke-8 dan seterusnya nilai $t_{\text {erms }}$ tetap berkurang namun selisih antara nilai $t_{\text {erms }}$ pada tiap iterasinya sangat kecil. Kecilnya nilai selisih ini menjadi anggapan bahwa model pada iterasi ke-12 sudah cukup merepresentasikan hasil yang diinginkan.

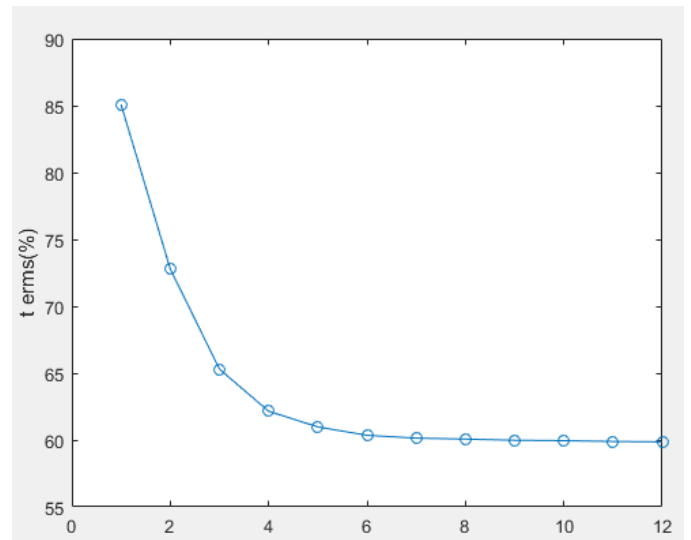

Gambar 14. Nilai terms pada setiap pembaharuan model
Untuk dapat melihat perbedaan hasil inversi yang dihasilkan, maka penulis akan menampilkan hasil inversi tomografi pada iterasi ke 1, 3, 5 dan 7. Penentuan ini bertujuan untuk melihat perubahan model kecepatan yang signifikan (iterasi 1,3 dan5) dan pada saat perubahan model yang relatif konstan (iterasi 5 dan 7).

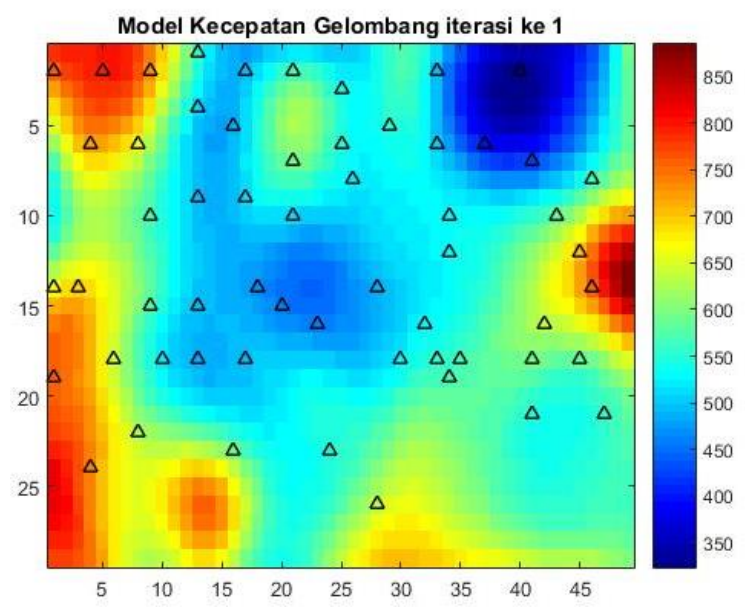

Gambar 15. Model kecepatan hasil inversi iterasi ke-1

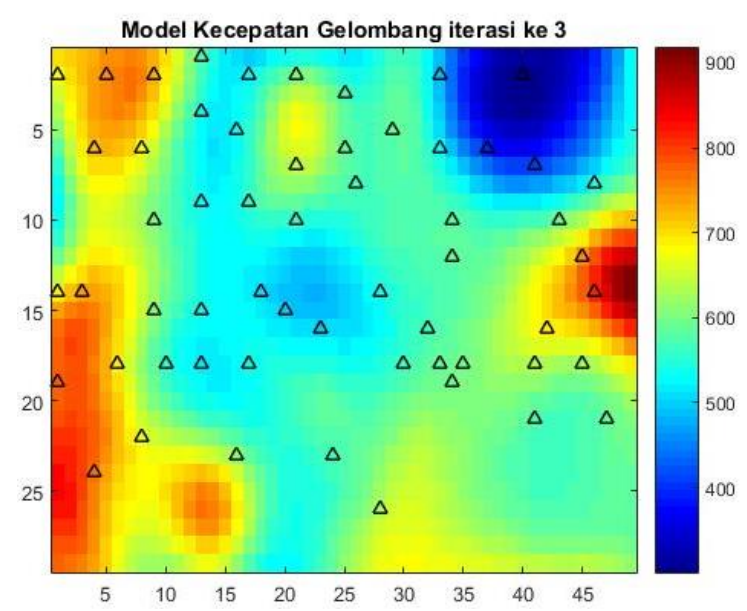

Gambar 16. Model kecepatan hasil inversi iterasi ke-3 


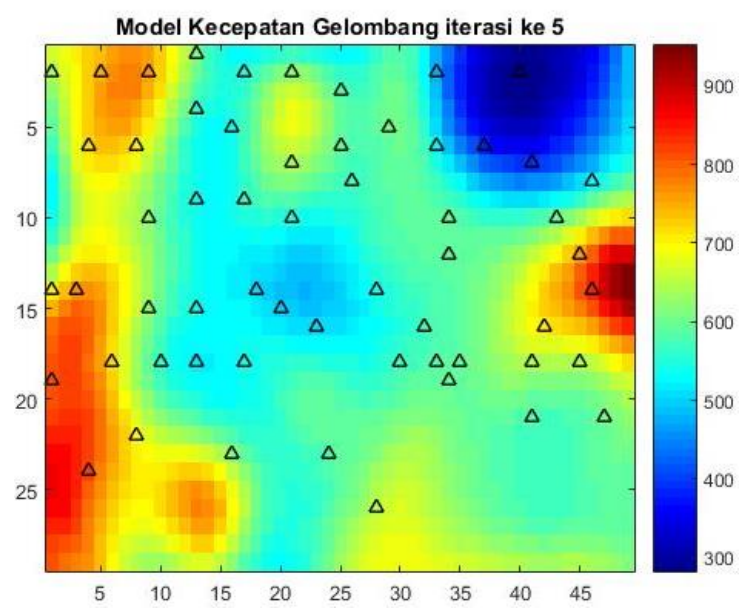

Gambar 17. Model kecepatan hasil inversi iterasi ke-5

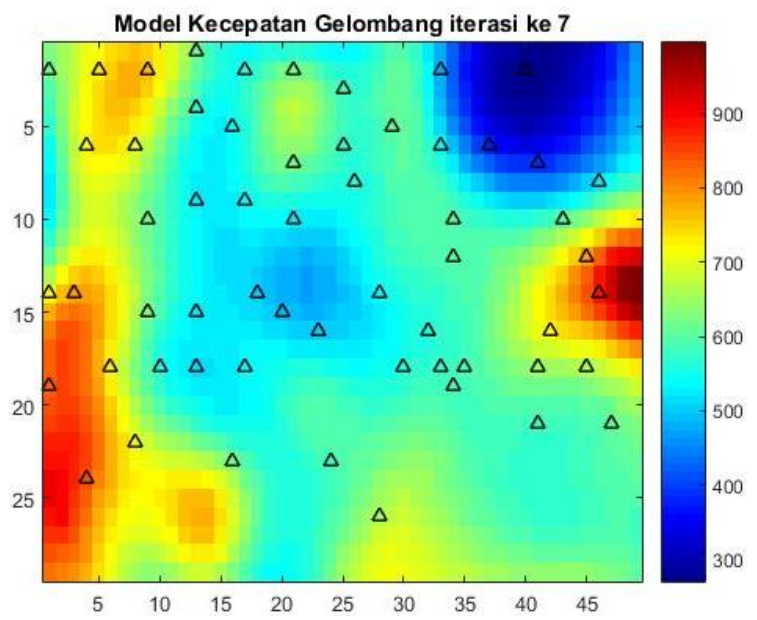

Gambar 18. Model kecepatan hasil inversi iterasi ke-7

Analisa hasil inversi dilakukan dengan mengambil model kecepatan hanya pada daerah dengan raypath coverage tinggi. Hal ini dikarenakan hasil inversi pada daerah tersebut diasumsikan menghasilkan model kecepatan yang mendekati dengan true model. Pada Gambar 15 - Gambar 18 merupakan model kecepatan didaerah yang ditandai dengan kotak berwarna merah pada Gambar 13 dengan iterasi yang berbeda-beda.

Dapat terlihat iterasi ke 1 (Gambar 15) dan iterasi ke 3 (Gambar 18) terdapat perubahan model kecepatan yang cukup signifikan. Pada bagian tengah iterasi ke 1 didominasi kecepatan sekitar 450 $-550 \mathrm{~m} / \mathrm{s}$, namun pada iterasi ke 3 kecepatan pada daerah tersebut menunjukkan perubahan kecepatan dimana kecepatan didominasi sekitar $500-600 \mathrm{~m} / \mathrm{s}$. Perubahan model kecepatan yang cukup signifikan juga ditemukan pada iterasi ke 3 dengan iterasi 5 . Pada iterasi ke 5, nilai kecepatan $500-600 \mathrm{~m} / \mathrm{s}$ lebih banyak mendominasi dibandingkan dengan iterasi 3 maupun iterasi ke 1 . Namun pada iterasi ke 7 tidak terlihat perubahan kecepatan yang signifikan. Hal ini sesuai dengan Gambar 14, dimana pada gambar tersebut menampilkan penurunan $t_{\text {erms }}$ yang cukup signifikan mulai dari iterasi 1 sampai iterasi 3. Untuk iterasi 4 dan seterusnya, tidak terjadi perubahan $t_{\text {erms }}$ yang signifikan, oleh karena itu penulis hanya menjalankan iterasi sampai dengan iterasi 10.

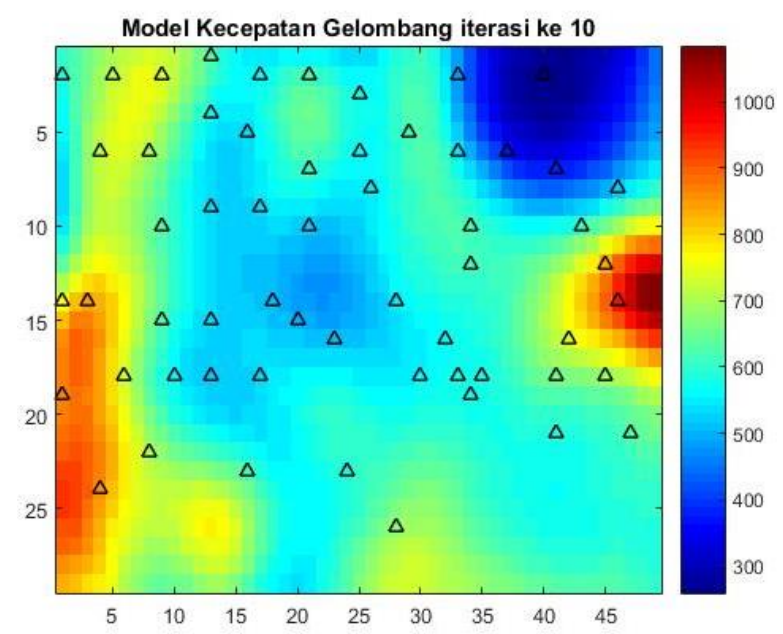

Gambar 19. Model kecepatan hasil inversi iterasi ke-12

Penulis melakukan analisa peta kecepatan gelombang pada model kecepatan iterasi 10. Hasil akhir inversi tomografi ditunjukkan pada Gambar 19. Kontras kecepatan gelombang dapat terlihat pada peta tersebut dalam rentang $300-1100 \mathrm{~m} / \mathrm{s}$. Pada Gambar 19 terdapat lingkaran merah yang menunjukkan adanya anomali high velocity serta low velocity. Nilai kecepatan gelombang pada anomali low velocity ialah $300-400 \mathrm{~m} / \mathrm{s}$ sedangkan pada high velocity ialah $900-1100 \mathrm{~m} / \mathrm{s}$. Di luar dari kedua anomali tersebut diasumsikan sebagai country rock dengan kecepatan gelombang bernilai $500-800 \mathrm{~m} / \mathrm{s}$.

Interpretasi yang dilakukan hanya sebatas penguraian perbedaan kecepatan gelombang dikarenakan tidak adanya data pendukung pada daerah penelitian seperti data bor, data seismik refraksi/refleksi ,dll. Dari peta kecepatan gelombang yang dihasilkan didapatkan 3 jenis struktur batuan yang berbeda. Hal ini didasarkan dari adanya perbedaan nilai kecepatan gelombang. Perbedaan kecepatan gelombang diakibatkan karena adanya perbedaan nilai properti batuan seperti, densitas batuan, porositas batuan, resisitivitas batuan, dll. Namun pada penelitian ini tidak dapat menentukan 
jenis batuan tersebut serta mengidentifikasi anomali tersebut dikarenakan kurangnya data pendukung seperti data bor, data seismik refleksi/refraksi, dII.

Munculnya kontras kecepatan gelombang membuktikan bahwa metode travel time tomography dapat digunakan menggunakan data seismik interferometri. Hasil travel time tomography menggunakan data seismik interferometri akan menghasilkan model kecepatan gelombang yang lebih baik apabila stacking trace pada pengolahan seismik interferometri lebih banyak, sehingga event-event pada trace seismic akan lebih terlihat serta pengolahan picking trace semakin akurat.

\section{PENUTUP}

\section{Simpulan dan Saran}

Berdasarkan penelitian traveltime tomography yang telah dilakukan, dapat ditarik kesimpulan yaitu metode traveltime tomography menggunakan data seismik yang telah diolah menggunakan perhitungan interferometri dapat menggambarkan model kecepatan gelombang. Terdapat pembaharuan model kecepatan gelombang dari model homogen hingga terdapat kontras kecepatan gelombang.

Hasil inversi tomografi menghasilkan kecepatan gelombang yang rendah dengan kisaran $40-200 \mathrm{~m} / \mathrm{s}$. Terdapat tiga daerah yang mengalami perubahan kenaikan kecepatan yang signifikan dari $40-80 \mathrm{~m} / \mathrm{s}$ pada iterasi 1 hingga $100-120 \mathrm{~m} / \mathrm{s}$ pada iterasi ke 12 .

Berdasarkan hasil penelitian yang telah dilakukan, penulis menyarankan pada penelitian selanjutnya dilakukan beberapa tahap tambahan serta perbaikan ialah pada penelitian ini, metode tomography dilakukan dengan data seismik interferometrl dengan waktu perekaman hanya 1 jam, sehingga yang dihasilkan dari picking tidak akurat. Sebaiknya gunakan metode tomography pada yang sudah akurat dengan menambah waktu perekaman pada proses pengolahan seismik interferometri.

Kemudian initial model berupa homogen merupakan usaha trial\&error dari penulis sehingga inversi tomografi yang dihasilkan kurang optimal. Perlu di tentukan initial model yang sesuai dengan data , dapat berupa refrensi penelitian maupun data geologi pada daerah penelitian.

\section{DAFTAR PUSTAKA}

Anshori, M., Maryanto, S. dan Rahman, T.D. (2014), "Pencitraan Tomografi Ambient Noise Untuk Menentukan Model Kecepatan Gelombang Rayleigh Di Pulau Jawa", Brawijaya Physics Student Journal, Vol.2, No.1. Diambil dari https://www.neliti.com/publications/159162/p encitraan-tomografi-ambient-noise-untukmenentukan-model-kecepatan-gelombang-ra.

Ben-Israel, A. dan Greville, T.N.E. (2003), Generalized Inverses: Theory and Applications, CMS Books in Mathematics, 2 Ed., Springer-Verlag, New York. Diambil

dari https://www.springer.com/gp/book/97803870 02934.

F. Aldridge, D. dan Oldenburg, D. (1993), "TwoDimensional Tomographic Inversion With Finite-Difference Traveltimes", Journal of Seismic Exploration, Vol.2.

Hidayatunnisak, S. (2015), "Studi Tomografi Seismik Untuk Menentukan Model Kecepatan Gelombang P Daerah Bali", Brawijaya Physics Student Journal, Vol.2, No.1. Diambil dari https://www.neliti.com/id/publications/159723 /studi-tomografi-seismik-untuk-menentukanmodel-kecepatan-gelombang-p-daerah-bali.

Monalia, P. (2011). Analisis Model Kecepatan Berdasarkan Tomografi Refleksi Waktu Tempuh (Travel Time Tomography Reflection), Tesis, Universitas Indonesia

Nicolson, H., Curtis, A., Baptie, B. dan Galetti, E. (2012), "Seismic interferometry and ambient noise tomography in the British Isles", Proceedings of the Geologists' Association, Vol.123, hal. 74-86. http://doi.org/10.1016/j.pgeola.2011.04.002.

Qin, F., Luo, Y., Olsen, K.B., Cai, W. dan Schuster, G.T. (1992), "Finite-difference solution of the eikonal equation along expanding wavefronts", GEOPHYSICS, Vol.57, No.3, hal. 478-487. http://doi.org/10.1190/1.1443263.

Rohatgi, V.K., Ben Israel, A., \& Greville, T. N. E. (1976). "Generalized Inverses: Theory and Application", International Statistical Review / Revue Internationale de Statistique, 44(2), 301. https://doi.org/10.2307/1403291 
Vidale, J. (1988), "Finite-Difference Calculation of Travel Times", Bulletin of the Seismological Society of America, Vol.78, No.6, hal. 2062-2076. 